\title{
Effect of Seed Distribution and Population on Maize (Zea mays L.) Grain Yield
}

\author{
Bee Khim Chim, Peter Omara, Natasha Macnack, Jeremiah Mullock, \\ Sulochana Dhital, and William Raun
}

Department of Plant and Soil Science, Oklahoma State University, Stillwater, OK 74075, USA

Correspondence should be addressed to William Raun; bill.raun@okstate.edu

Received 15 May 2014; Accepted 14 November 2014; Published 9 December 2014

Academic Editor: Othmane Merah

Copyright (c) 2014 Bee Khim Chim et al. This is an open access article distributed under the Creative Commons Attribution License, which permits unrestricted use, distribution, and reproduction in any medium, provided the original work is properly cited.

\begin{abstract}
Maize planting is normally accomplished by hand in the developing world where two or more seeds are placed per hill with a heterogeneous plant spacing and density. To understand the interaction between seed distribution and distance between hills, experiments were established in 2012 and 2013 at Lake Carl Blackwell (LCB) and Efaw Agronomy Research Stations, near Stillwater, OK. A randomized complete block design was used with three replications and 9 treatments and a factorial treatment structure of 1,2 , and 3 seeds per hill using interrow spacing of $0.16,0.32$, and $0.48 \mathrm{~m}$. Data for normalized difference vegetation index (NDVI), intercepted photosynthetically active radiation (IPAR), grain yield, and grain $\mathrm{N}$ uptake were collected. Results showed that, on average, NDVI and IPAR increased with number of seeds per hill and decreased with increasing plant spacing. In three of four site-years, planting 1 or 2 seeds per hill, $0.16 \mathrm{~m}$ apart, increased grain yield and $\mathrm{N}$ uptake. Over sites, planting 1 seed, every $0.16 \mathrm{~m}$, increased yields by an average of $1.15 \mathrm{Mg} \mathrm{ha}^{-1}$ (range: 0.33 to $2.46 \mathrm{Mg} \mathrm{ha}^{-1}$ ) when compared to the farmer practice of placing 2 to 3 seeds per hill, every $0.48 \mathrm{~m}$.
\end{abstract}

\section{Introduction}

Seed spacing, a practice that determines the spatial distribution of plants, affects canopy structure, light interception, and radiation use efficiency and, consequently, biomass or grain yield [1]. Different spatial arrangements produced by changes in row spacing can affect appropriate plant density and, therefore, resource competition relationships which are crucial in crop productivity $[1,2]$. Most importantly, the population and distribution of plants are believed to have a profound effect on grain yield. Wade et al. [3] observed that the population of plants per square meter (density) and arrangement of individual plants within a square meter determine nutrient use and grain yield of maize. Uneven distribution of plants can reduce grain yield compared to uniform distribution at the same density [3]. Extreme uneven plant distribution can reduce grain yield up to $30 \%$ [4]. Doerge et al. [5] reported that yield can be increased up to $0.25 \mathrm{Mg} \mathrm{ha}^{-1}$ for each $2.54 \mathrm{~cm}$ improvement in the plant spacing standard deviation. They added that individual plant yields were at a maximum when plants were within 0.05 to 0.07 meters of perfect equidistant spacing. However, Liu et al. [6] noted that plant spacing which results in a perfectly uniform plant distribution has no yield advantage over nonequidistant plant spacing. Narrowing plant spacing can allow plants to take spatial advantage and increase resource capture and utilization $[7,8]$. Some studies conducted do not conclude any significant yield advantage in narrowing plant spacing [9]. Grain yield increases with increasing plant density and then comes to a plateau at some point, above which increasing plant population is not economical. This is because, above the plant population that gives the maximum grain yield, the reduction in grain yield due to crowding stress cannot be compensated by increasing plant stands [10]. The strongest possible effect of plant competition for nutrients and other factors is observed when plants are growing very near to or even in contact with each other. The extent to which plant density affects grain yield depends on the hybrid and other environmental conditions $[4,10,11]$.

Plant population and row width determine light interception and consequently photosynthesis and yield [12]. 
Papadopoulos and Pararajasingham [13] noted that it is possible to manipulate plant spacing to maximize light interception in any crop. Nafziger [14] observed that, within the normal range of crop population, the increase in crop yield from increasing plant population is related to the increase in light interception. He further noted that maximizing light interception during grain production is of paramount importance to optimum grain yield. Board et al. [15] observed greater light interception in the narrow row culture $(0.5 \mathrm{~m})$ compared to the wide row culture $(1 \mathrm{~m})$. They noted that this occurred during vegetative and early reproductive periods of plant growth. Similarly, Zhang et al. [16] noted that the best distribution of light is attained in systems with narrow strips and high plant densities. Increasing plant density through narrow row planting of maize could increase light interception and consequently increase grain yield. Just like other resources, nitrogen $(\mathrm{N})$ uptake seems to be closely related to plant spacing. Ciampitti and Vyn [17] reported high $\mathrm{N}$ uptake and use efficiency in narrow rows with a high plant density. Narrowing maize rows enables plants to occupy spaces between plants, utilizing the applied $\mathrm{N}$ fertilizer that would otherwise be lost. A similar study by Barbieri et al. [18] found that $\mathrm{N}$ uptake increased with narrow row spacing. They realized a $15 \%$ increase in $\mathrm{N}$ uptake expressed as grain yield with narrow maize rows. Many studies have been conducted on crop spacing, seed distribution, and $\mathrm{N}$ utilization. However, little attempt has been made to explain the relationship and interaction between these factors and the resulting effects on maize grain yield. If maize grain yield can be improved by reducing plant spacing as demonstrated by Widdicombe and Thelen [7], it is important to determine whether it is possible to manipulate seed distribution to improve $\mathrm{N}$ utilization and grain yield. The objective of this study was to determine the combined effects of distance between hills and number of seeds planted per hill on maize grain yield and $\mathrm{N}$ uptake.

\section{Materials and Methods}

Experiments were conducted in the summer of 2012 and 2013 at Lake Carl Blackwell (LCB) and Efaw Agronomy Research Station near Stillwater, OK, to evaluate the effect of seed distribution and population on maize grain yield. Lake Carl Blackwell is situated on a Pulaski fine-sandy loam soil while Efaw Agronomy Research Station is on an Ashport silty clay loam. A randomized complete block design was used in all experiments with three replications and 9 treatments. The treatment structure consisted of a complete factorial of 1,2 , and 3 seeds per hill at interplant spacing of $0.16,0.32$, and $0.48 \mathrm{~m}$. All treatments were planted with the corn hybrid Pioneer P1498HR at a row spacing of $0.76 \mathrm{~m}$. A solid wood stick with a pointed tip similar to those used in Central and South America was used to open each planting hole (hill). Seeds were placed in the hole and then covered by foot. A uniform rate of 180 and $130 \mathrm{~kg} \mathrm{Nha}^{-1}$ as urea preplant was applied to all treatments in 2012 and 2013, respectively. Preand postemergence herbicides were used as needed to control weeds. All experiments were irrigated on days during the growing season when little or no rainfall was anticipated.
Experimental plots were sensed using the active Greenseeker (handheld optical sensor, Trimble, Ukiah, CA, USA) at V4, V6, and V8 maize growth stages [19] to determine the normalized difference vegetation index (NDVI). Intercepted photosynthetically active radiation (IPAR) was collected using a Line Quantum Sensor (Li-COR, USA) at the V6 maize growth stage. At maturity, experimental plots were harvested using a Massey Ferguson 8XP (Massey Ferguson, Duluth, GA, USA) self-propelled combine. Subsamples were collected for each plot and dried in an oven at $65^{\circ} \mathrm{C}$ for $48 \mathrm{~h}$. The samples were then ground to pass through a $1 \mathrm{~mm}$ sieve size. Finely ground samples were achieved via rolling internal stainless steel pins within small glass bottles for $24 \mathrm{~h}$. Total N was determined using a LECO Truspec CN dry combustion analyzer [20]. Treatment effects on maize grain yield, grain $\mathrm{N}$ content, and IPAR and NDVI values were evaluated using the PROC GLM procedure and treatment means separated using the least significant difference (LSD) with SAS (SAS Institute, Inc., Cary, NC, USA).

\section{Results}

3.1. Grain Yield. In 2012, emergence difference and plant death at Efaw resulted in 1-10\% fewer plants than the target population (Table 1). There was a strong positive linear relationship between harvested plant population and ears harvested with an $r^{2}$ of 0.97 (Table 2). Analysis of variance showed that number of seeds per hill and the interaction between plant spacing and seeds per hill had a significant $(P<0.01)$ effect on grain yield (Table 3$)$. The highest grain yield $\left(11.68 \mathrm{Mg} \mathrm{ha}^{-1}\right.$ ) was found at $0.48 \mathrm{~m}$ spacing with 3 seeds per hill while the lowest yield $\left(6.51 \mathrm{Mg} \mathrm{ha}^{-1}\right)$ was obtained at $0.48 \mathrm{~m}$ spacing with 1 seed per hill. However, the former was not significantly different from yield at $0.32 \mathrm{~m}$ spacing with 3 seeds per hill (11.26 $\left.\mathrm{Mg} \mathrm{ha}^{-1}\right)$ and $0.16 \mathrm{~m}$ spacing with 1 seed per hill $\left(11.06 \mathrm{Mg} \mathrm{ha}^{-1}\right)$.

Grain yield at $0.16 \mathrm{~m}$ spacing decreased with number of seeds per hill while those at 0.32 and $0.48 \mathrm{~m}$ spacing increased. The interaction between number of seeds per hill and interplant spacing is shown in Figure 1. A comparison of harvest population and seeding rate indicated emergence differences and plant death of $28-35 \%$ at the LCB site (Table 1). There was a poor linear relationship between harvest population and ears harvested with an $r^{2}$ of 0.47 (Table 2). Analysis of variance indicated that plant spacing, number of seeds per hill, and the interaction did not significantly $(P>0.05)$ affect grain yield (Table 4$)$. The $0.16 \mathrm{~m}$ spacing gave the highest yield $\left(3.80 \mathrm{Mg} \mathrm{ha}^{-1}\right)$ across number of seeds per hill while $0.32 \mathrm{~m}$ spacing had the lowest yield with $2.49 \mathrm{Mg} \mathrm{ha}^{-1}$. Figure 2 illustrates the general trend of maize grain yields as affected by seeds per hill and plant spacing.

In 2013, emergence difference resulted in 33-70\% fewer plant stands than the target population (Table 1). However, there was a positive linear relationship between harvest population and ears harvested with $r^{2}$ of 0.99 (Table 2). Analysis of variance indicated that maize grain yields were significantly different $(P<0.01)$ for the number of seeds per hill, interplant spacing, and the interaction (Table 5). 


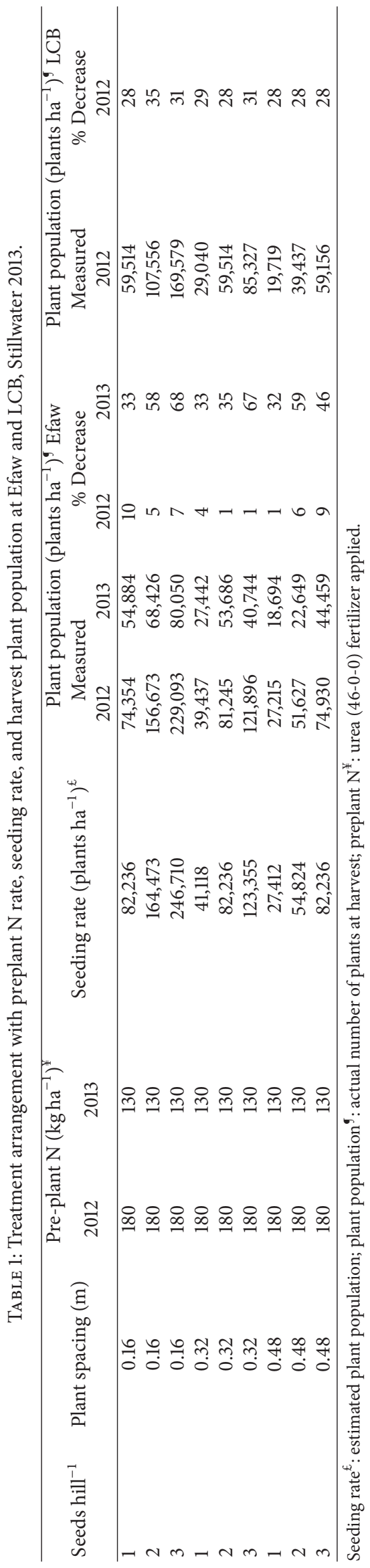


TABLE 2: Linear regression results including coefficient of variation, $r^{2}$, slope, and slope significance for the relationship between grain yield with normalized difference vegetation index (NDVI) and intercepted photosynthetically active radiation (IPAR) and between plant population at harvest and number of ears harvested at LCB and Efaw locations, 2012 and 2013.

\begin{tabular}{|c|c|c|c|c|c|c|}
\hline Year & Dependent variable & Independent variable & C.V (\%) & Slope & Slope significance & Model $r^{2}$ \\
\hline \multicolumn{7}{|c|}{ Efaw } \\
\hline 2012 & Grain yield & V8 NDVI & 16.5 & 15.60 & $<0.0001^{* * *}$ & 0.53 \\
\hline 2012 & Grain yield & IPAR & 23.6 & 0.01 & $0.3201^{\mathrm{ns}}$ & 0.04 \\
\hline 2013 & Grain yield & V8 NDVI & 16.0 & 16.00 & $<0.0001^{* * *}$ & 0.61 \\
\hline 2013 & Grain yield & IPAR & 29.3 & 6.10 & $0.0011^{* * *}$ & 0.32 \\
\hline 2012 & Plant population & Number of ears & 7.1 & 0.74 & $<0.0001^{* * *}$ & 0.97 \\
\hline 2013 & Plant population & Number of ears & 4.1 & 0.94 & $<0.0001^{* * *}$ & 0.99 \\
\hline \multicolumn{7}{|c|}{$\mathrm{LCB}$} \\
\hline 2012 & Grain yield & IPAR & 42.0 & 4.14 & $0.1196^{\mathrm{ns}}$ & 0.10 \\
\hline 2012 & Grain yield & V8 NDVI & 44.0 & 3.10 & $0.2835^{\mathrm{ns}}$ & 0.05 \\
\hline 2012 & Plant population & Number of ears & 39.5 & 0.40 & $<0.0001^{* * *}$ & 0.47 \\
\hline
\end{tabular}

C.V: coefficient of variation; $r^{2}$ : regression coefficient; ${ }^{* * *}$ significant at 0.01 level of probability; ns: not significant.

TABLE 3: Analysis of variance for normalized difference vegetation index (NDVI) values, intercepted photosynthetically active radiation (IPAR), grain yield $\left(\mathrm{Mg} \mathrm{ha}^{-1}\right)$, and $\mathrm{N}$ content (\%) at Efaw, 2012.

\begin{tabular}{|c|c|c|c|c|c|c|c|}
\hline \multicolumn{2}{|c|}{ Sources of variation } & NDVI V4 & NDVI V6 & NDVI V8 & IPAR & Grain yield $\left(\mathrm{Mg} \mathrm{ha}^{-1}\right)$ & $\mathrm{N}$ content $(\%)$ \\
\hline & & \multicolumn{6}{|c|}{ Mean Square } \\
\hline \multicolumn{2}{|c|}{ Seeds per hill } & $0.0738^{* * *}$ & $0.0151^{\mathrm{ns}}$ & $0.0600^{* * *}$ & $0.0334^{\mathrm{ns}}$ & $11.46^{* * *}$ & $0.0025^{\mathrm{ns}}$ \\
\hline \multicolumn{2}{|c|}{ Plant spacing } & $0.1225^{* * *}$ & $0.0613^{* * *}$ & $0.0756^{* * *}$ & $0.0828^{* * *}$ & $6.39^{\mathrm{ns}}$ & $0.0075^{\mathrm{ns}}$ \\
\hline \multicolumn{2}{|c|}{ Seeds per hill $\times$ spacing } & $0.0034^{* *}$ & $0.0054^{\mathrm{ns}}$ & $0.0035^{\mathrm{ns}}$ & $0.0031^{\mathrm{ns}}$ & $12.58^{* * *}$ & $0.0071^{\mathrm{ns}}$ \\
\hline Seeds per hill & Spacing & \multicolumn{6}{|c|}{ Treatment means } \\
\hline 1 & 0.16 & 0.4200 & 0.5633 & 0.7567 & 0.6133 & 11.06 & 1.25 \\
\hline 1 & 0.32 & 0.3100 & 0.6167 & 0.6000 & 0.4700 & 6.8 & 1.27 \\
\hline 1 & 0.48 & 0.2600 & 0.4800 & 0.5100 & 0.4233 & 6.51 & 1.19 \\
\hline 2 & 0.16 & 0.5700 & 0.6933 & 0.8100 & 0.6967 & 9.97 & 1.14 \\
\hline 2 & 0.32 & 0.4100 & 0.6400 & 0.7533 & 0.4933 & 10.58 & 1.26 \\
\hline 2 & 0.48 & 0.3333 & 0.4800 & 0.6400 & 0.5633 & 7.42 & 1.22 \\
\hline 3 & 0.16 & 0.6667 & 0.7167 & 0.8467 & 0.7300 & 9.6 & 1.17 \\
\hline 3 & 0.32 & 0.4900 & 0.6367 & 0.7833 & 0.5833 & 11.26 & 1.21 \\
\hline 3 & 0.48 & 0.3733 & 0.5500 & 0.7133 & 0.5500 & 11.68 & 1.25 \\
\hline SED & & 0.02 & 0.05 & 0.03 & 0.09 & 1.27 & 0.06 \\
\hline C.V (\%) & & 7 & 11 & 5.7 & 19 & 16.4 & 6.2 \\
\hline
\end{tabular}

***,** Significant at 0.01 and 0.05 levels of probability, respectively; ns: not significant; SED: standard error of the difference between two equally replicated means; C.V: coefficient of variation.

The highest maize grain yields $\left(8.97 \mathrm{Mg} \mathrm{ha}^{-1}\right)$ were harvested at $0.16 \mathrm{~m}$ spacing with one seed per hill while the lowest yield $\left(4.01 \mathrm{Mg} \mathrm{ha}^{-1}\right)$ was obtained at $0.32 \mathrm{~m}$ spacing with one seed per hill. Figure 3 illustrates the interaction for plant spacing and the number of seeds per hill on maize grain yield. Yield at $0.16 \mathrm{~m}$ spacing decreased with number of seeds per hill while those at 0.32 and $0.48 \mathrm{~m}$ spacing increased with number of seeds per hill, as also seen in 2012. Due to extremely poor emergence and seedling performance, results for 2013 for LCB were not included in this report.

3.2. Intercepted Photosynthetically Active Radiation (IPAR). In 2012, analysis of variance showed that IPAR was significantly different for plant spacing $(P<0.01)$ but not number of seeds per hill and the interaction (Table 3). Overall, IPAR increased with the number of seeds per hill from 50 to $62 \%$ and decreased with plant spacing from 68 to $51 \%$. At the LCB site, no significant effects were observed for all treatments including the interaction. In 2013, IPAR was significantly different for both number of seeds per hill $(P<0.05)$ and distance between hills $(P<0.01)$ but not for the interaction (Table 5). There was an overall increase of $19 \%$ in IPAR values as seeds per hill increased from 1 to 3 , while a small decrease of $1 \%$ was observed with increasing plant spacing. In 2012, there was no significant linear relationship between IPAR and grain yield ( $r^{2}$ of 0.04 ), and although the relationship was significant in 2013, the model had a relatively low $r^{2}$ of 0.32 (Table 2). 
TABLE 4: Analysis of variance for normalized difference vegetation index (NDVI) values, intercepted photosynthetically active radiation (IPAR), grain yield $\left(\mathrm{Mg} \mathrm{ha}^{-1}\right)$, and $\mathrm{N}$ content (\%) at LCB, 2012.

\begin{tabular}{|c|c|c|c|c|c|c|c|}
\hline \multicolumn{2}{|c|}{ Sources of variation } & NDVI V4 & NDVI V6 & NDVI V8 & IPAR & Grain yield $\left(\mathrm{Mg} \mathrm{ha}^{-1}\right)$ & $\mathrm{N}$ content $(\%)$ \\
\hline & & \multicolumn{6}{|c|}{ Mean square } \\
\hline \multicolumn{2}{|c|}{ Seeds per hill } & $0.0102^{* *}$ & $0.0232^{* * *}$ & $0.0275^{* * *}$ & $0.0110^{\mathrm{ns}}$ & $0.9218^{\mathrm{ns}}$ & $0.0005^{\mathrm{ns}}$ \\
\hline \multicolumn{2}{|c|}{ Plant spacing } & $0.0013^{\mathrm{ns}}$ & $0.0011^{\mathrm{ns}}$ & $0.0414^{* * *}$ & $0.0126^{* *}$ & $3.3182^{\mathrm{ns}}$ & $0.0135^{\mathrm{ns}}$ \\
\hline \multicolumn{2}{|c|}{ Seeds per hill $\times$ spacing } & $0.0016^{\mathrm{ns}}$ & $0.0039^{\mathrm{ns}}$ & $0.0115^{* *}$ & $0.0051^{\mathrm{ns}}$ & $1.8859^{\mathrm{ns}}$ & $0.0062^{\mathrm{ns}}$ \\
\hline Seeds per hill & Spacing & \multicolumn{6}{|c|}{ Treatment means } \\
\hline 1 & 0.16 & 0.2785 & 0.2905 & 0.4480 & 0.2600 & 2.8250 & 1.4600 \\
\hline 1 & 0.32 & 0.2743 & 0.3213 & 0.4617 & 0.2833 & 2.5567 & 1.5433 \\
\hline 1 & 0.48 & 0.2115 & 0.2655 & 0.4075 & 0.2500 & 2.3200 & 1.4950 \\
\hline 2 & 0.16 & 0.2917 & 0.3613 & 0.6167 & 0.2520 & 3.8800 & 1.4967 \\
\hline 2 & 0.32 & 0.2650 & 0.3235 & 0.4015 & 0.2095 & 1.9750 & 1.5150 \\
\hline 2 & 0.48 & 0.2690 & 0.3250 & 0.4273 & 0.1977 & 3.7600 & 1.4767 \\
\hline 3 & 0.16 & 0.3330 & 0.4235 & 0.6635 & 0.3760 & 4.6450 & 1.3750 \\
\hline 3 & 0.32 & 0.3125 & 0.3540 & 0.5895 & 0.3195 & 2.9050 & 1.5350 \\
\hline 3 & 0.48 & 0.3440 & 0.4477 & 0.4400 & 0.1967 & 2.0333 & 1.5400 \\
\hline SED & & 0.04 & 0.05 & 0.04 & 0.05 & 1.15 & 0.08 \\
\hline C.V (\%) & & 16 & 18 & 11 & 22 & 47 & 6 \\
\hline
\end{tabular}

***,** Significant at 0.01 and 0.05 levels of probability, respectively; ns: not significant; SED: standard error of the difference between two equally replicated means; C.V: coefficient of variation.

TABLE 5: Analysis of variance for normalized difference vegetation index (NDVI) values, intercepted photosynthetically active radiation (IPAR), grain yield $\left(\mathrm{Mg} \mathrm{ha}^{-1}\right)$, and $\mathrm{N}$ content (\%) at Efaw, 2013.

\begin{tabular}{|c|c|c|c|c|c|c|c|}
\hline \multicolumn{2}{|c|}{ Source of variation } & NDVI V4 & NDVI V6 & NDVI V8 & IPAR & Grain yield $\left(\mathrm{Mg} \mathrm{ha}^{-1}\right)$ & $\mathrm{N}$ content $(\%)$ \\
\hline & & \multicolumn{6}{|c|}{ Mean square } \\
\hline \multicolumn{2}{|c|}{ Seeds per hill } & $0.0239^{* * *}$ & $0.0189^{* * *}$ & $0.0309^{* * *}$ & $0.0537^{* *}$ & $9.66^{* * *}$ & $0.0142^{\mathrm{ns}}$ \\
\hline \multicolumn{2}{|c|}{ Plant spacing } & $0.0004^{\mathrm{ns}}$ & $0.0002^{\mathrm{ns}}$ & $0.0584^{* * *}$ & $0.1442^{* * *}$ & $18.12^{* * *}$ & $0.0048^{\mathrm{ns}}$ \\
\hline \multicolumn{2}{|c|}{ Seeds per hill $\times$ spacing } & $0.0011^{* *}$ & $0.0022^{* * *}$ & $0.0012^{* * *}$ & $0.0021^{* * *}$ & $5.61^{* * *}$ & $0.0109^{\mathrm{ns}}$ \\
\hline Seeds per hill & Spacing & \multicolumn{6}{|c|}{ Treatment means } \\
\hline 1 & 0.16 & 0.4135 & 0.5098 & 0.7057 & 0.5211 & 8.97 & 1.11 \\
\hline 1 & 0.32 & 0.4179 & 0.5649 & 0.5764 & 0.3328 & 4.01 & 1.20 \\
\hline 1 & 0.48 & 0.4238 & 0.5276 & 0.5163 & 0.3088 & 4.25 & 1.22 \\
\hline 2 & 0.16 & 0.5062 & 0.6025 & 0.7932 & 0.629 & 7.81 & 1.03 \\
\hline 2 & 0.32 & 0.4914 & 0.5952 & 0.6647 & 0.404 & 6.51 & 1.15 \\
\hline 2 & 0.48 & 0.4685 & 0.5692 & 0.6474 & 0.3614 & 5.55 & 1.12 \\
\hline 3 & 0.16 & 0.5493 & 0.6456 & 0.802 & 0.7039 & 7.43 & 1.17 \\
\hline 3 & 0.32 & 0.5196 & 0.6234 & 0.7288 & 0.5603 & 7.17 & 1.09 \\
\hline 3 & 0.48 & 0.5636 & 0.6643 & 0.6667 & 0.4582 & 7.02 & 1.09 \\
\hline SED & & 0.01 & 0.01 & 0.01 & 0.1 & 0.52 & 0.06 \\
\hline C.V (\%) & & 3.6 & 2.5 & 1.6 & 26.2 & 9.1 & 6.6 \\
\hline
\end{tabular}

***,** Significant at 0.01 and 0.05 levels of probability, respectively; ns: not significant; SED: standard error of the difference between two equally replicated means; C.V: coefficient of variation.

3.3. Normalized Difference Vegetation Index (NDVI). In 2012, NDVI was significantly different for number of seeds per hill, plant spacing $(P<0.01)$, and the interaction $(P<0.05)$ at the V4 growth stage at Efaw. At V6, NDVI was significantly different for plant spacing $(P<0.01)$ but not number of seeds per hill. At the V8 growth stage, NDVI was significantly different for both plant spacing and number of seeds per hill but not for the interaction (Table 3). At LCB, nonsignificant increases in NDVI values were observed at all three growth stages (V4, V6, and V8). In 2013, NDVI at V4 and V6 growth stages were significantly different for number of seeds per hill, but not plant spacing. At V8, NDVI was significantly different for number of seeds per hill, plant spacing, and the interaction (Table 5). At the V8 growth stage, NDVI and yield were highly correlated in both 2012 and 2013 at Efaw $\left(r^{2}\right.$ of 0.53 and 0.61 , resp., Table 2). 


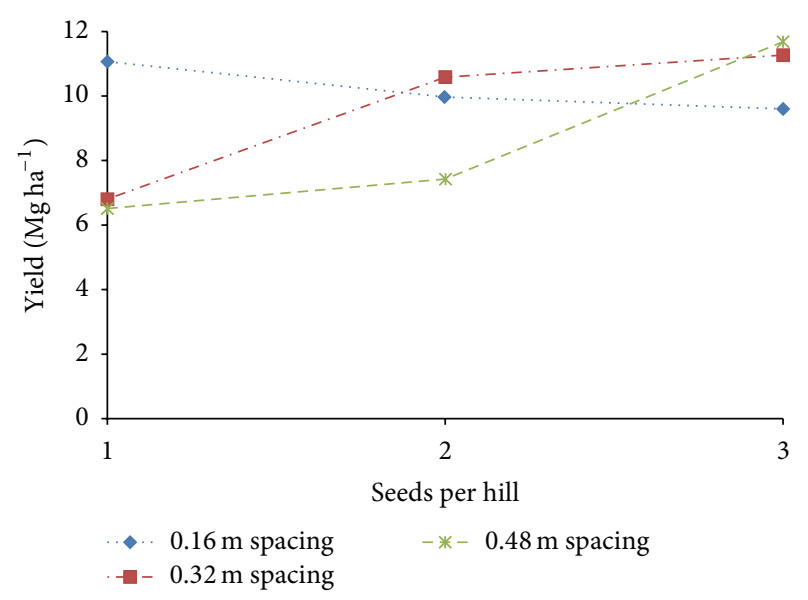

FIGURE 1: The interaction effects of plant spacing $(0.16 \mathrm{~m}, 0.32 \mathrm{~m}$, and $0.48 \mathrm{~m}$ ) and number of seeds per hill (1,2, and 3 ) on grain yields $\left(\mathrm{Mg} \mathrm{ha}^{-1}\right)$ averaged across replication at Efaw, 2012.

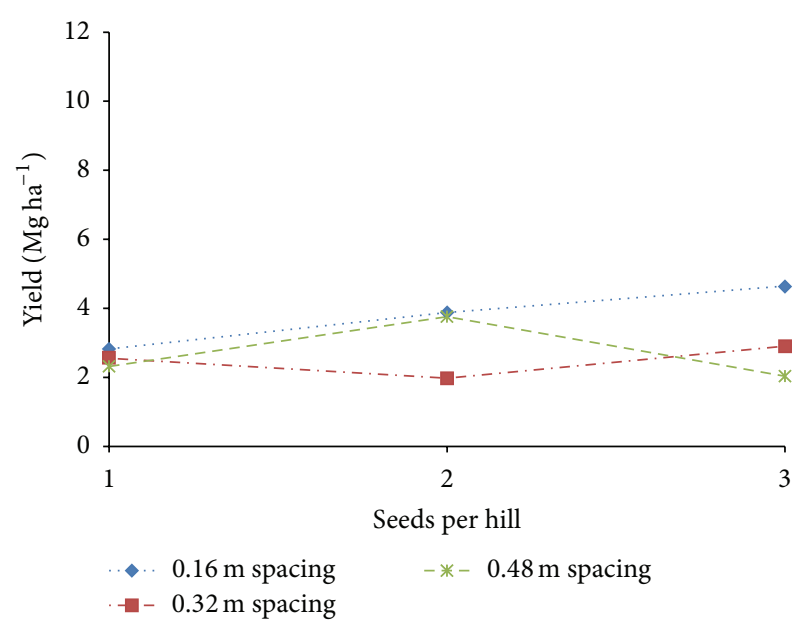

Figure 2: Grain yield $\left(\mathrm{Mg} \mathrm{ha}^{-1}\right)$ averaged across replications as influenced by plant spacing $(0.16 \mathrm{~m}, 0.32 \mathrm{~m}$, and $0.48 \mathrm{~m})$ and the number of seeds per hill (1, 2, and 3) at Lake Carl Blackwell (LCB) location, 2012.

3.4. Grain Nitrogen (N) Content. In 2012, no significant difference in $\mathrm{N}$ concentration was observed for all treatments at both the Efaw and LCB sites. At Efaw, the highest grain $\mathrm{N}$ content $(1.27 \%)$ was observed when maize was planted at $0.32 \mathrm{~m}$ spacing with one seed per hill while the lowest grain $\mathrm{N}$ content (1.14\%) was observed at $0.16 \mathrm{~m}$ spacing with two seeds per hill (Table 3 ). Grain N content at $0.16 \mathrm{~m}$ spacing decreased when number of seeds increased from one to two to three seeds per hill $(1.25,1.14$, and $1.17 \%$, resp.). At $0.32 \mathrm{~m}$ grain $\mathrm{N}$ decreased with number of seeds per hill from 1.27 to $1.21 \%$. Grain $\mathrm{N}$ content at $0.48 \mathrm{~m}$ spacing increased with number of seeds per hill from 1.19 to $1.25 \%$. In 2013, there were no differences in grain $\mathrm{N}$ concentration at the Efaw location. The highest grain $\mathrm{N}$ of $1.22 \%$ was achieved at $0.48 \mathrm{~m}$ spacing with one seed per hill while the lowest $\mathrm{N}$ content of $1.04 \%$ occurred at $0.16 \mathrm{~m}$ spacing with two seeds per hill. There was a general decrease in grain $\mathrm{N}$ with increasing number of seeds per hill

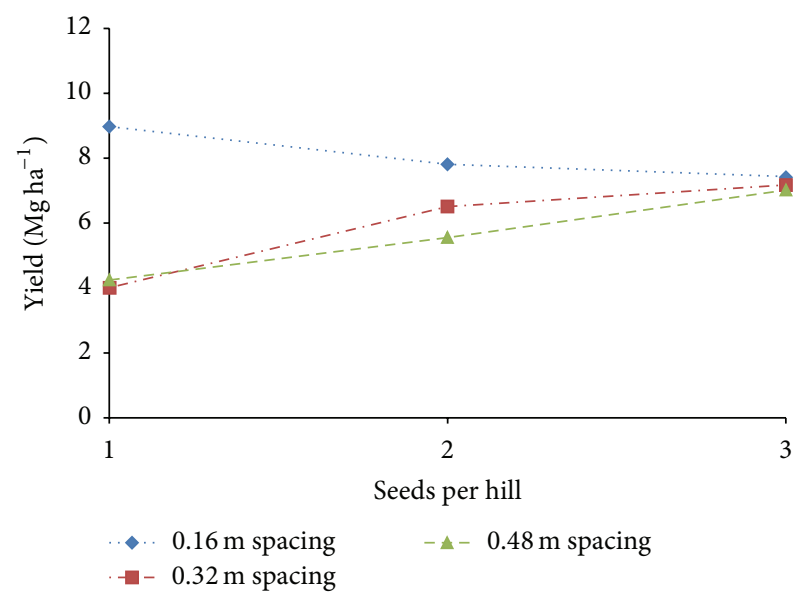

FIgURE 3: The interaction effects of plant spacing $(0.16 \mathrm{~m}, 0.32 \mathrm{~m}$, and $0.48 \mathrm{~m}$ ) and number of seeds per hill (1,2, and 3 ) on grain yields $\left(\mathrm{Mg} \mathrm{ha}^{-1}\right)$ averaged across replication at Efaw, 2013.

over plant spacing. In general, grain $\mathrm{N}$ content increased with increased plant spacing and seeds per hill.

\section{Discussion}

4.1. Grain Yield. Higher number of seeds per hill resulted in more aborted plants and decreased ear weight. Considering all years and locations, the maximum grain yields were attained with plant population ranging from 60,000 to 90,000 plants per hectare. Grain yield decreased with the number of seeds/hill when planted at the $0.16 \mathrm{~m}$ spacing. At this narrow spacing, increased competition would be expected, and yields were indeed lower due to the excessive number of plants. However, at the $0.48 \mathrm{~m}$ spacing, the opposite was observed; as the number of seeds per hill increased from one to three, yield increased. This too would be expected since the wider distances between plant placements would allow for less competitive growth and development of more plants. This trend was observed in both years at Efaw, but not at Lake Carl Blackwell. At Lake Carl Blackwell, no significant differences were observed likely due to the extremely low grain yields.

4.2. Intercepted Photosynthetically Active Radiation (IPAR). Intercepted photosynthetically active radiation (IPAR) increased with number of seeds per hill and decreased with increased interplant spacing in both years and locations. At lower plant spacing, there are more plants with a thicker canopy to intercept light. The increased number of seeds per hill provides for a more dense plant canopy with comparatively more soil cover. Indeed, greater light interception would be observed in these scenarios. In a similar study, Zhang et al. [16] observed that narrow plant spacing with higher stand density increased light interception. However, capturing more light should not necessarily result in increased grain yield. Keating and Carberry [21] elaborated that plants could take spatial advantage of intercepted light due to increased soil cover. This would not necessarily offset competition at a later stage of plant development, in effect, 
lowering grain yield. Sharratt and McWilliams [22] noted that increases in IPAR at close spacing and/or dense plant stands mean that equal or more water and nutrients are used. This observation supports results from the current study that show increased light interception with closer plant spacing and increased number of seeds per hill. However, light interception explained only $30 \%$ or less of the variability in maize grain yield.

4.3. Normalized Difference Vegetation Index (NDVI). The overall decrease in NDVI with increasing plant spacing was because of decreased ground cover and increased bare soil surface in between plant stands. Also, increasing number of seeds per hill provided for thicker plant canopy; NDVI values would be expected to increase. A similar study by Lukina et al. [23] found that NDVI decreased with an increase in plant spacing. They explained that decreased NDVI with plant spacing was a result of increased bare soil surface which has higher reflectance in the visible than near-infrared region of the spectrum. Trout et al. [24] found a strong linear relationship between canopy cover and NDVI with a correlation coefficient $\left(r^{2}\right)$ of 0.95 . Higher crop canopy covers indicate higher biomass and therefore increased NDVI values. The two studies above agree with the present study that closer plant spacing and increased number of seeds per hill increase NDVI values. Regression analysis showed a fairly strong linear relationship with NDVI explaining up to $60 \%$ of the variability in grain yield.

4.4. Grain Nitrogen (N) Content. The interaction between plant spacing and number of seeds per hill did not significantly affect grain $\mathrm{N}$ uptake. Grain $\mathrm{N}$ content was high at Lake Carl Blackwell compared to Efaw. There was an inverse relationship between grain $\mathrm{N}$ content and yield. As yield increased, grain $\mathrm{N}$ content decreased, implying that high grain protein was expected when yields were low. Grain N content decreased with number of seeds per hill. This could be because of increased competition between the increasing numbers of seeds per hill for the same $\mathrm{N}$ quantity in the soil. Grain N content also increased with plant spacing. Nitrogen uptake was lowest at narrow interrow spacing $(0.16 \mathrm{~m})$ compared to wider interrow spacing $(0.48 \mathrm{~m})$. This finding is however contrary to studies by Barbieri et al. [18]; Ciampitti and Vyn [17]; both found that narrowing plant spacing increased the number of plants per square meter and increased $\mathrm{N}$ uptake.

\section{Conclusions}

Increasing the number of seeds per hill in the present study increased competition between plants and lowered grain yield. However, there was no advantage in grain $\mathrm{N}$ concentration by varying interrow plant spacing and/or number of seeds per hill within the range used in this study. High grain $\mathrm{N}$ was found in years and/or locations where yields were low. In general, NDVI and IPAR increased as number of seeds per hill increased. Overall, this study confirmed that the maximum maize grain yield was observed with one seed per hill and that grain yield decreased by 12 to $15 \%$ if more than 1 seed was placed in the same hill. Maize planting at narrow interrow spacing $(0.16 \mathrm{~m})$ with one seed per hill reduced seeding rate by $66 \%$ compared to planting three seeds per hill at the same spacing. Grain yields were in general higher when one seed was planted within a narrow $(0.16 \mathrm{~m})$ seed to seed spacing.

\section{Conflict of Interests}

The authors declare that there is no conflict of interests regarding the publication of this paper.

\section{References}

[1] J. Mattera, L. A. Romero, A. L. Cuatrín, P. S. Cornaglia, and A. A. Grimoldi, "Yield components, light interception and radiation use efficiency of lucerne (Medicago sativa $\mathrm{L}$.) in response to row spacing," European Journal of Agronomy, vol. 45, pp. 87-95, 2013.

[2] M. Worku and T. Astatkie, "Row and plant spacing effects on yield and yield components of soya bean varieties under hot humid tropical environment of Ethiopia," Journal of Agronomy and Crop Science, vol. 197, no. 1, pp. 67-74, 2011.

[3] L. J. Wade, C. P. Norris, and P. A. Walsh, "Effects of suboptimal plant density and non-uniformity in plant spacing on grain yield of rain-grown sunflower," Australian Journal of Experimental Agriculture, vol. 28, pp. 617-622, 1988.

[4] L. J. Wade and A. C. L. Douglas, "Effect of plant density on grain yield and yield stability of sorghum hybrids differing in maturity," Australian Journal of Experimental Agriculture, vol. 30, pp. 257-264, 1990.

[5] T. Doerge, T. Hall, and D. Gardner, "New research confirms benefits of improved plant spacing in corn," Crop Insights, vol. 12 , no. 2, 2002.

[6] W. Liu, M. Tollenaar, G. Stewart, and W. Deen, "Within-row plant spacing variability does not affect corn yield," Agronomy Journal, vol. 96, no. 1, pp. 275-280, 2004.

[7] W. D. Widdicombe and K. D. Thelen, "Row width and plant density effects on corn grain production in the Northern Corn Belt," Agronomy Journal, vol. 94, no. 5, pp. 1020-1023, 2002.

[8] J. L. de Bruin and P. Pedersen, "Effect of row spacing and seeding rate on soybean yield," Agronomy Journal, vol. 100, no. 3, pp. 704-710, 2008.

[9] D. E. Farnham, "Row spacing, plant density, and hybrid effects on corn grain yield and moisture," Agronomy Journal, vol. 93, no. 5, pp. 1049-1053, 2001.

[10] W. G. Duncan, "A theory to explain the relationship between corn population and grain yield," Agronomy Journal, vol. 24, pp. 1141-1145, 1984.

[11] S. Fukai and M. A. Foale, "Effects of row spacing on growth and grain yield of early and late sorghum cultivars," Australian Journal of Experimental Agriculture, vol. 28, pp. 771-777, 1988.

[12] D. W. Stewart, C. Costa, L. M. Dwyer, D. L. Smith, R. I. Hamilton, and B. L. Ma, "Canopy structure, light interception, and photosynthesis in maize," Agronomy Journal, vol. 95, no. 6, pp. 1465-1474, 2003.

[13] A. P. Papadopoulos and S. Pararajasingham, "The influence of plant spacing on light interception and use in greenhouse tomato (Lycopersicon esculentum Mill.): a review," Scientia Horticulturae, vol. 69, no. 1-2, pp. 1-29, 1997.

[14] E. D. Nafziger, "Inter and Intra-plant competition in corn," Crop Management, vol. 5, no. 1, 2006. 
[15] J. E. Board, M. Kamal, and B. G. Harville, "Temporal importance of greater light interception to increased yield in narrowrow soybean," Agronomy Journal, vol. 84, pp. 575-579, 1992.

[16] L. Zhang, W. van der Werf, L. Bastiaans, S. Zhang, B. Li, and J. H. J. Spiertz, "Light interception and utilization in relay intercrops of wheat and cotton," Field Crops Research, vol. 107, no. 1, pp. 29-42, 2008.

[17] I. A. Ciampitti and T. J. Vyn, "A comprehensive study of plant density consequences on nitrogen uptake dynamics of maize plants from vegetative to reproductive stages," Field Crops Research, vol. 121, no. 1, pp. 2-18, 2011.

[18] P. A. Barbieri, H. E. Echeverría, H. R. Saínz Rozas, and F. H. Andrade, "Nitrogen use efficiency in maize as affected by nitrogen availability and row spacing," Agronomy Journal, vol. 100, no. 4, pp. 1094-1100, 2008.

[19] Iowa State University, "How a corn plant develops: Special Report No. 48," Cooperative Extension Service, Ames Iowa, USA, 1993, http://www.virtual.chapingo.mx/dona/paginaCBasicos/howgrowcorn.pdf.

[20] J. S. Schepers, D. D. Francis, and M. T. Thompson, "Simultaneous determination of total $\mathrm{C}$, total $\mathrm{N}$ and $15 \mathrm{~N}$ on soil and plant material," Communications in Soil Science and Plant Analysis, vol. 20, pp. 949-959, 1989.

[21] B. A. Keating and P. S. Carberry, "Resource capture and use in intercropping: solar radiation," Field Crops Research, vol. 34, no. 3-4, pp. 273-301, 1993.

[22] B. S. Sharratt and D. A. McWilliams, "Microclimatic and rooting characteristics of narrow-row versus conventional-row corn," Agronomy Journal, vol. 97, no. 4, pp. 1129-1135, 2005.

[23] E. V. Lukina, W. R. Raun, M. L. Stone et al., "Effect of row spacing, growth stage, and nitrogen rate on spectral irradiance in winter wheat," Journal of Plant Nutrition, vol. 23, no. 1, pp. 103-122, 2000.

[24] T. J. Trout, L. F. Johnson, and J. Gartung, "Remote sensing of canopy cover in horticultural crops," HortScience, vol. 43, no. 2, pp. 333-337, 2008. 


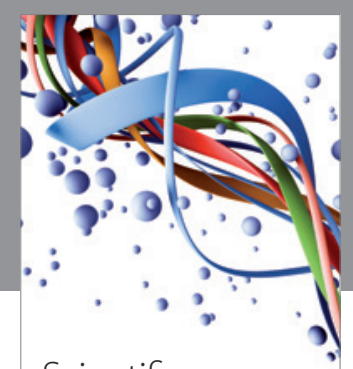

Scientifica
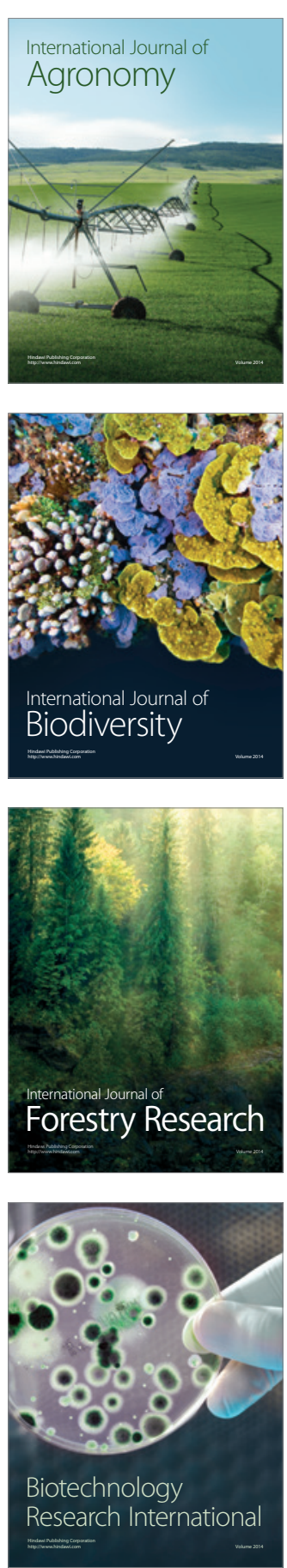
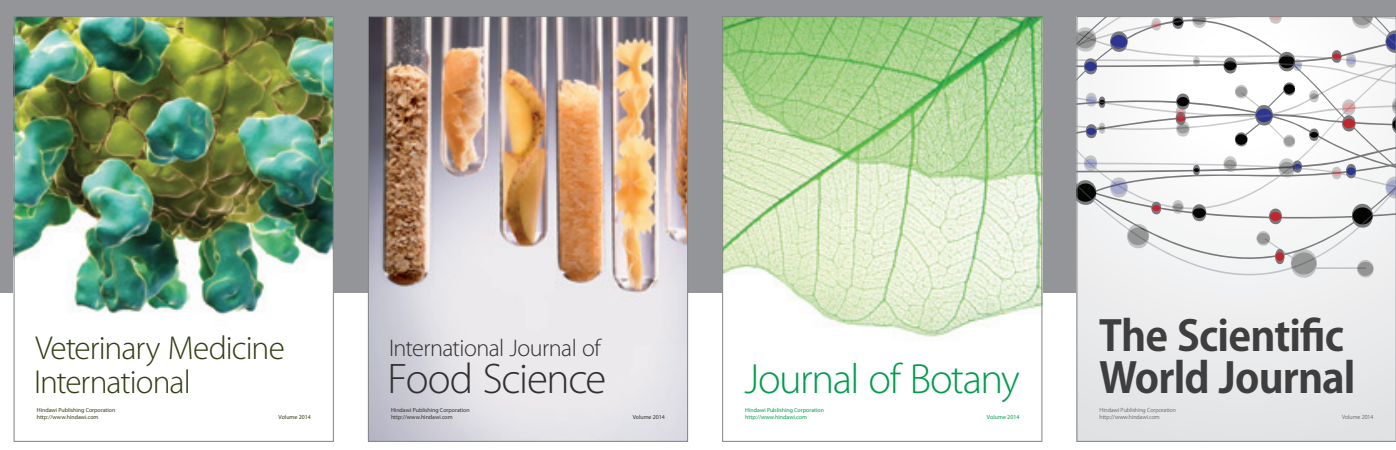

The Scientific World Journal
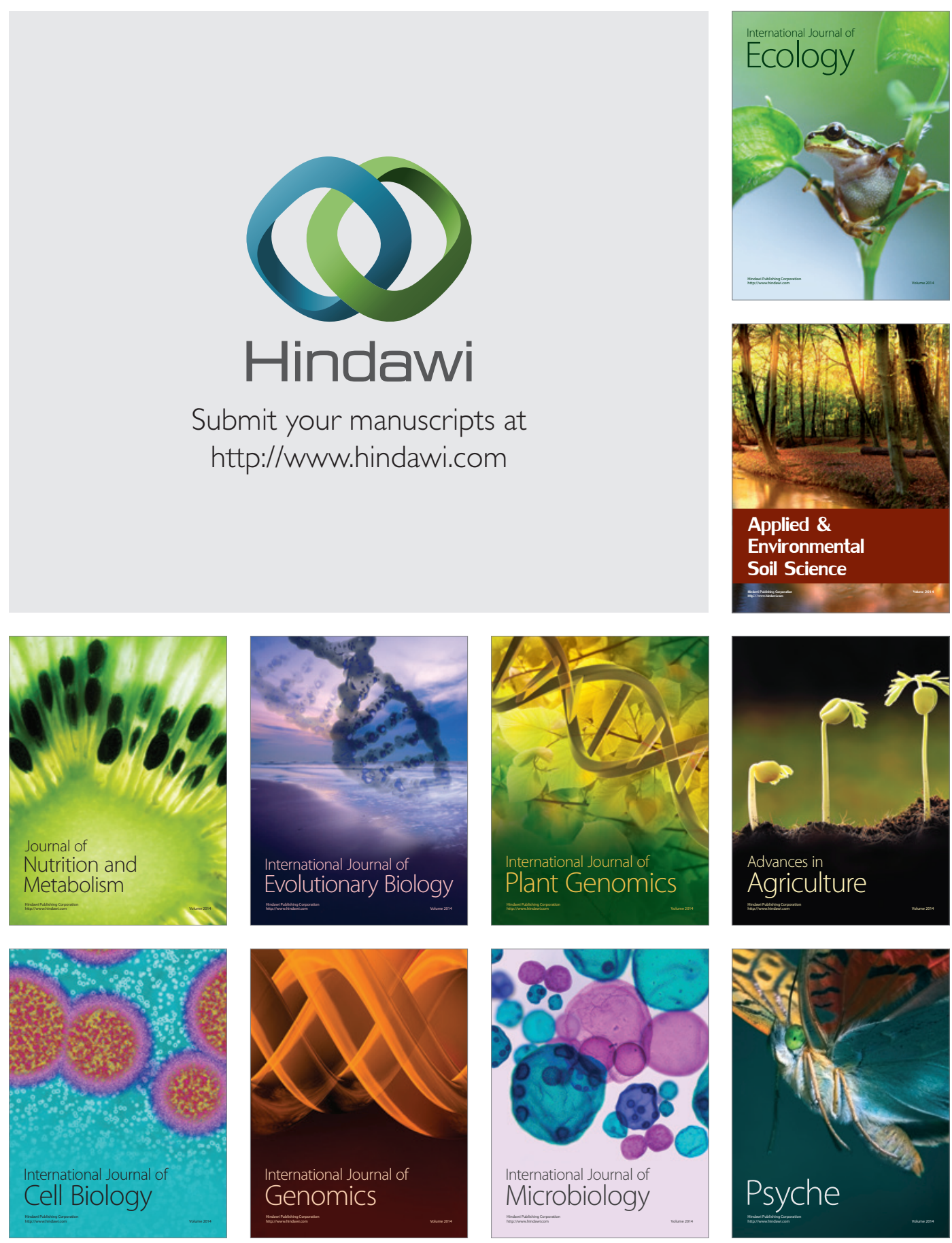